\title{
ROMAN MEDAN: SEJARAH KARYA SASTRA DI KOTA MEDAN (1930-1965)
}

\author{
Oleh: \\ Melly Tria Utari \\ Ika Purnama Sari
}

\begin{abstract}
Abstrak
Penelitian ini bertujuan untuk menjelaskan latar belakang penulisan roman Medan, perkembangan roman Medan pada masa Kolonial Belanda hingga Orde Lama, serta dampak penulisan roman Medan bagi masyarakat Kota Medan. Hasil dari penelitian ini menunjukkan bahwa perkembangan roman Medan pada masa Kolonial Belanda (19121942), mengalami kemajuan yang begitu pesat. Sehingga pada tahun 1930-an roman Medan berada di puncak kejayaannya, hingga muncul istilah Banjir Roman yang ditandai dengan banyaknya roman yang terbit. Bahkan secara kuantitas roman Medan yang dicetak oleh percetakan swasta ini mampu bersaing dengan roman terbitan Balai Pustaka, yang mana Balai Pustaka merupakan penerbit buku yang telah didirikan terlebih dahulu oleh pemerintah Belanda untuk disalurkan ke seluruh Indonesia. Akan tetapi, pada masa pendudukan Jepang (1942-1945) roman Medan mengalami kemunduran bahkan hilang dari peredaran, dan pada masa Awal Kemerdekaan (1945-1950) hingga masa Orde Lama (1950-1966), roman Medan bangkit kembali akan tetapi eksistensinya tidak seperti dahulu. Selain itu, penulisan roman Medan ini memiliki dampak terhadap kehidupan masyarakat Medan diantaranya dalam Bidang Politik, Pendidikan, Sosial dan Budaya.
\end{abstract}

Kata Kunci: Roman Medan, Sejarah Karya Sastra, Medan 


\section{PENDAHULUAN}

Roman memiliki ceritanya sendiri dan memiliki daya pikatnya tersendiri yang dapat menarik para pembacanya. Salah satu wilayah yang menjadi tempat berkembangnya roman dengan cukup pesat ialah Kota Medan. Roman yang berkembang di Medan ini disebut Roman Medan. Tentunya penamaan ini dikarena-kan roman ini terbit dan dicetak di Medan. Roman Medan merupakan ciri khas dari sastra Kota Medan, yang biasanya menceritakan mengenai kehidup-an sehari-hari masyarakat kota Medan selain itu pada ceritanya yang sangat pro terhadap rakyat kecil dan anti kolonialisme, sehingga banyakmasyarakat Kota Medan tertarik pada karya sastra ini.

Hadirnya roman-roman yang dikelompokkan sebagai roman Medan tidak terlepas dari diberlakukannya politik etis di Indonesia. Politik etis yang diterapkan oleh Belanda tersebut mempengaruhi perkembangan dunia pendidikan di Indonesia, baik pendidikan Barat maupun pendidikan Islam. Namun, pendidikan Islam tidak mendapatkan kesempatan yang sama untuk mengembangkan diri dibandingkan dengan orang-orang yang berpendidikan Barat. Di satu pihak, pemerintahan Belanda dengan segala upaya berusaha memperkuat dan mempertahankan kekuasaannya, sedangkan di pihak lain umat Islam Indonesia berdaya upaya untuk melepaskan diri dari cengkeraman kekuasaan tersebut (Sayekti, 2011: 733)

Dengan adanya penulisan roman Medan ini para sastrawan dapat mengungkapkan bagaimana situasi kota Medan pada saat itu, yang nantinya diharapkan akan mampu mengubah pandangan serta menambah pengetahuan masyarakat terhadap rasa nasionalisme dalam menghadapi kepentingan politik pemerintahan Belanda, karena Belanda pada masa itu tidak hanya berusaha untuk menguasai Indonesia dalam bidang ekonomi saja, tetapi juga berusaha menguasai Indonesia dalam bidang kebudayaan khususnya pada bidang kesusastraan.

Maka dari itu cerita roman Medan yang ditulis ini tidak seperti yang banyak dibayangkan oleh orang-orang yang mana dianggap sebagai tulisan yang dikemas dalam kisah-kisah percintaan muda-mudi saja, melainkan roman Medan juga memunculkan semangat kebangsaan dan anti kolonialisme. Hal ini disebabkan karena pengarang roman Medan pada umumnya adalah orang-orang muda yang aktif di dunia pergerakan dan memiliki semangat anti penjajahan. 
Dalam perkembangannya roman Medan pernah mengalami masa kejayaan pada tahun 1930an sampai 1940an, hingga muncul istilah Banjir Roman hal ini dapat dilihat dari banyaknya kuantitas roman yang terbit yaitu dalam sebulan ada 15 roman, setahun 180 roman dan dalam waktu lima tahun sampai 900 roman. Bahkan roman Medan yang dicetak oleh percetakan swasta ini mampu bersaing dengan buku-buku terbitan Balai Pustaka, yang mana Balai Pustaka merupakan penerbit buku yang telah didirikan terlebih dahulu oleh pemerintah Belanda untuk disalurkan ke seluruh Indonesia. Akan tetapi, pada masa pendudukan Jepang roman Medan mengalami kemunduran bahkan sempat terhenti, namun roman Medan bangkit kembali pada tahun 1947 sampai 1965.

Roman Medan memiliki dampak yang cukup besar bagi masyarakat Kota Medan seperti di bidang politik, di bidang pendidikan, di bidang sosial dan budaya. Sayekti (2011: 735) mengatakan bahwa beberapa karya roman Medan memunculkan tema pergerakan sehingga dapat menimbulkan rasa kebangsaan (nasionalisme). Wujud rasa kebangsaan yang muncul dalam karya-karya tersebut di antaranya keikutsertaan tokohtokoh dalam karya-karya roman medan dalam organisasi politik yang ada pada saat itu. Selain itu, tidak hanya sebagai bahan bacaan hiburan belaka, tetapi roman Medan juga merupakan salah satu cara untuk mempertahankan identitas kemelayuan di Kota Medan. Selain untuk mempertahankan identitas kemelayuan, karya-karya roman medan diduga memiliki potensi yang kuat sebagai karya yang dapat menggambarkan bagaimana rasa kebangsaan dan semangat anti kolonialisme dibangun pada masa itu.

Adapun metode yang digunakan dalam penelitian ini (Sjamsuddin, 2012: 86) yaitu dengan menggunakan metode sejarah yang dikaji melalui empat tahapan yaitu heuristik (pengumpulan sumber), verifikasi data, interpretasi data (penafsiran), dan historiografi (penulisan sejarah). Sedangkan teknik analisis data yang dilakukan oleh penulis dalam menganalisis kajian mengenai sejarah karya sastra ini menggunakan pendekatan diakronis yang merupakan pendekatan yang memanjang dalam waktu, namun secara ruang terbatas.

Penulisan sejarah karya sastra dengan pendekatan diakronis ini dilakukan dengan cara mementingkan prosesnya sehingga berupaya untuk melihat suatu peristiwa sejarah karya sastra khususnya roman Medan dari sudut pandang rentang waktu. Pendekatan diakronis ini menganalisis evolusi dari waktu sehingga lebih menekankan perubahan dari masa-masa lampau yang bersifat vertikal (Sulasman, 2014: 26-27). 


\section{II.PEMBAHASAN}

\section{A. Awal Penulisan Roman Medan}

Awal penulisan roman Medan dimulai dengan adanya politik etis yang dilakukan oleh Belanda, dimana tumbuh kemelekhurufan dalam masyarakat yang lebih luas karena program pendidikan pemerintah jajahan. Selain itu juga dikarenakan perbedaan kesempatan dalam pendidikan Barat dan pendidikan Islam yang dilakukan Belanda.

Akibat pendidikan yang didapatkan dari penjajahan Belanda, rakyat Indonesia mulai mengenal baca-tulis hingga munculnya organisasi pergerakan sehingga mengakibatkan tumbuhnya semangat nasionalisme dan ingin melepaskan diri dari penjajahan. Khususnya dalam bidang literasi yang sebagian besar didominasi oleh pengarang-pengarang muslim di Kota Medan mereka menunjukkan kemampuan menulisnya dan berusaha untuk menumbuhkan semangat nasionalisme dan anti penjajahan itu lewat roman Medan.

Selain itu tokoh penulisan roman Medan juga terdiri dari berbagai golongan sehingga mereka memiliki banyak ideologi dalam menulis karya sastra, ada yang berlandaskan aturan sastra, berlandaskan hukum Islam, berideologi komunis, dan ada juga yang independen. Ciri khusus Roman Medan ini ialah ditulis dan terbit di percetakan swasta di Medan. Selain itu ciri roman Medan sendiri yaitu sangat erat dengan ceritanya yang dapat menggambarkan kondisi Medan dan masyarakatnya, termasuk ketika adanya tulisan tentang sistem perkebunan pada masa Kolonial.

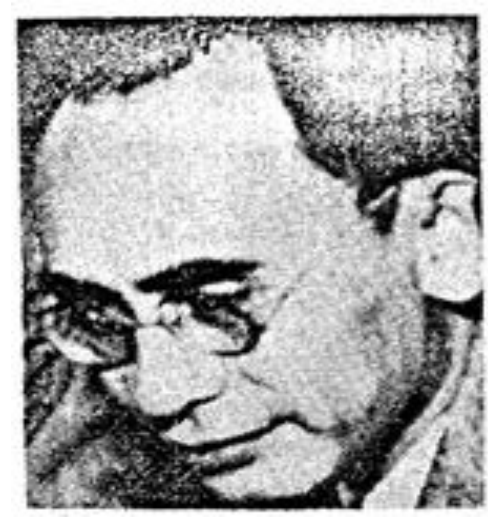

Gambar 1: Joesoef Souy'b. Seorang ulama lokal dan kolumnis yang terkenal sebagai salah seorang pengarang roman Medan. (Sumber: ensiklopedia kemdikbud) 


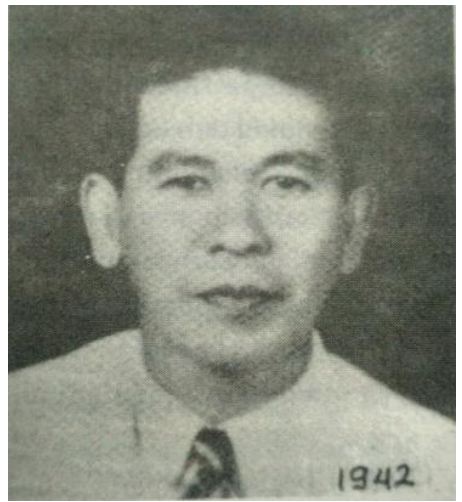

Gambar 2: Abdoe'1 Xarim M.S. Penulis roman yang menonjol dalam berpolitik.

(Sumber: Roman Medan Sebuah Kota Membangun Harapan, 2018)

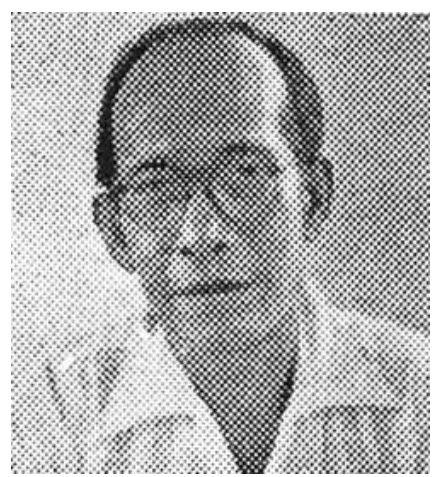

Gambar 3: Matu Mona. Pengarang roman sensasional dan wartawan surat kabar Pewarta Deli di Medan. (Sumber: Roman Medan Sebuah Kota Membangun Harapan, 2018)

\section{B. Perkembangan Roman Medan}

Perkembangan roman Medan dari masa ke masa yaitu Pertama, Perkembangan roman Medan pada masa Kolonial Belanda (1912-1942), pada masa ini roman Medan mengalami perkembangan yang signifikan. Seperti kutipan Sapardi Djoko Damono (Zaidan, dkk. 2005: 163) yang mengatakan bahwa:

"Pembaca boleh pikir: sebulan ada 15 roman yang terbit, setahun $12 \times 15=180$,

zegge seratus delapan puluh roman... Lima taun total jenderal sembilan ratus roman ... Amboi, tidakkan ini akan menegakkan bulu roma pendengarnya: rupanya roman ini sudah boleh pula dijadikan julo-julo modern, asal ada wang, lahir majalah roman. Roman telah dijadikan sumber kepalsuan dan banjir wang”.

Kutipan itu menunjukkan betapa khawatirnya penulis akan 'banjir roman', produksi sejenis novel pendek secara besar-besaran pada masa itu. Kuantitas roman Medan yang mengalami kenaikan begitu pesat tidak terlepas dari hasrat untuk berkarya dan kecintaan terhadap dunia karang-mengarang serta hasrat menggebu untuk memunculkan penerbitan lokal yang selama ini terpendam sudah tak terbendung lagi. 
Tahun 1939 muncul penerbit roman bulanan dengan nama "Loekisan Poedjangga" yang dilakukan oleh penerbit "Tjerdas". Kemudian tampil penerbit "Indische Drukkrij" dan NV. Sjarikat Tapanuli di Medan. Larisnya buku-buku roman Medan menuai banyak kritik dengan alasan klise seperti tak mendidik, bahkan penulisnya dikecam sebagai "pujangga surau", sebab roman Medan pada waktu itu isinya bercerita detektif, kejahatan, pencurian dan pembunuhan seperti karya Joesoef Sou'yb (Amin, 2015: 99).

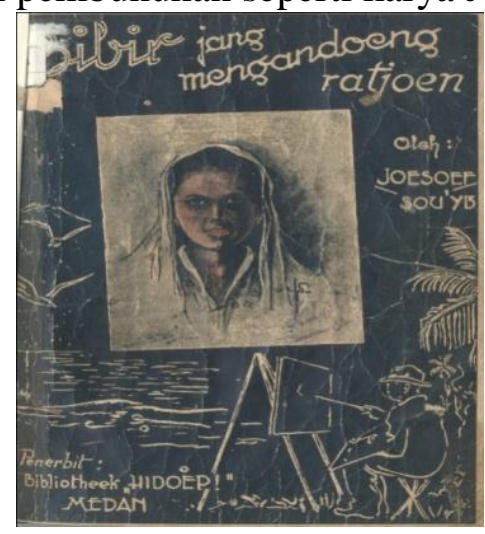

Gambar 4: Roman Bibir jang Mengandoen Ratcoen (1938), menceritakan pembunuhan yang dilakukan seorang pelukis akibat kisah percintaan. (Sumber: Seminar Sejarah dan Pameran Roman Medan, oleh Mahasiswa Pendidikan Sejarah B reg '15 Unimed. Medan, 31 Maret 2018)

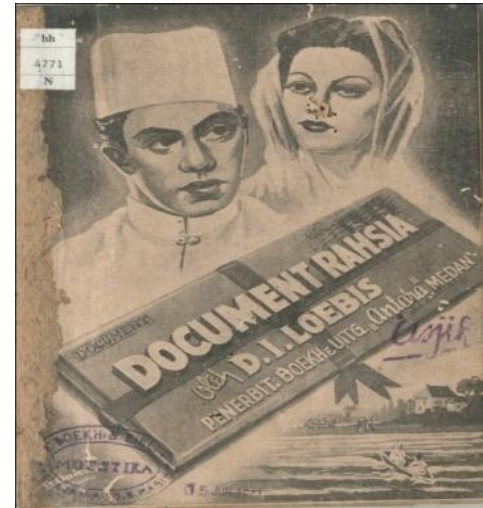

Gambar 5: Roman Document Rahsia (1941), mengungkapkan serba-serbi kehidupan pelarian pembawa dokumen yang penuh dengan ketegangan. (Sumber: Seminar Sejarah dan Pameran Roman Medan, oleh Mahasiswa Pendidikan Sejarah B reg '15 Unimed. Medan, 31 Maret 2018)

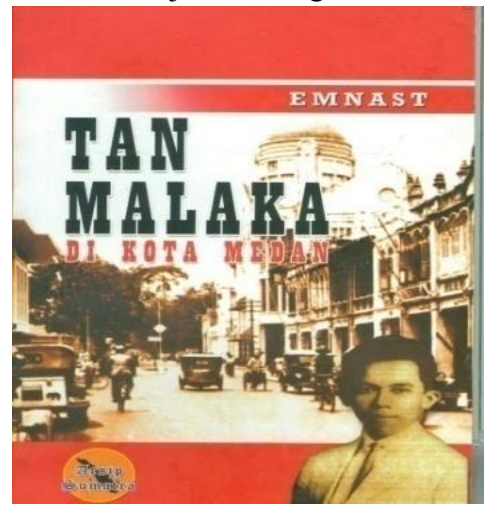

Gambar 6:Roman Tan Malaka di Kota Medan (1941) menceritakan keberadaan Tan Malaka di Medan.(Sumber: Seminar Sejarah dan Pameran Roman Medan, oleh Mahasiswa Pendidikan Sejarah B reg '15 Unimed. Medan, 31 Maret 2018) 
Kedua, Perkembangan roman Medan pada masa Pendudukan Jepang (1942-1945), pada masa ini roman Medan mengalami kemunduran. Hal tersebut diakibatkan karena kebijakan dari pemerintahan Kolonial Jepang membuat terhentinya penerbitan roman di Sumatera Utara, akibat ketatnya sensor yang dilakukan oleh serdadu Jepang.

Ketiga, Perkembangan roman Medan pada masa Awal Kemerdekaan (1945-1950), pada masa Indonesia berdaulat secara hukum dan politik, para pengarangnya bangkit kembali. Mereka menginginkan kebebasan berekspresi melalui karya sastra tanpa aturan yang mengekang. Tulisan mereka pun semakin kritis hingga lahirlah karya-karya yang banyak mengungkapkan kesengsaraan dan penderitaan rakyat dalam menghadapi kolonial

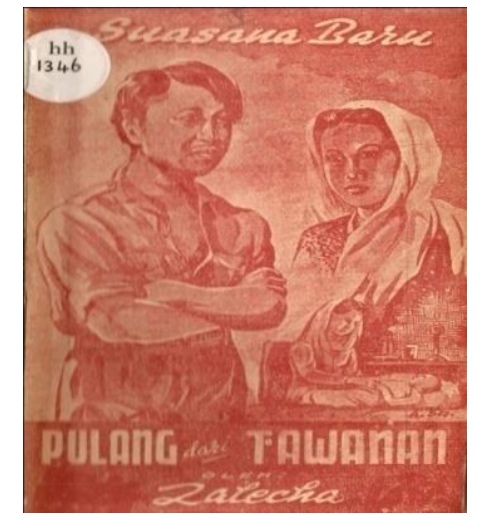

Gambar 7: Roman Pulang dari Tawanan (1948). Menceritakan kisah cinta sepasang kekasih yang penuh rintangan pada masa Kolonial.

(Sumber: Seminar Sejarah dan Pameran Roman Medan, oleh Mahasiswa Pendidikan Sejarah B reg '15 Unimed. Medan, 31 Maret 2018)

Keempat, Perkembangan roman Medan pada masa Orde Lama (1950- 1966), pada masa ini sensor terhadap roman Medan masih berlaku. Sensor dipergunakan untuk membatasi roman yang dianggap cabul, dan roman yang naskahnya selesai diperiksa dan lulus sensor akan diperbolehkan beredar. Walau begitu, pada masa orde lama roman Medan tetap menunjukkan banyaknya kuantitas roman yang terbit, hal ini dapat dilihat dari banyaknya badan penerbitan resmi yang bisa mengedarkan buku-buku ke seluruh penjuru tanah air.

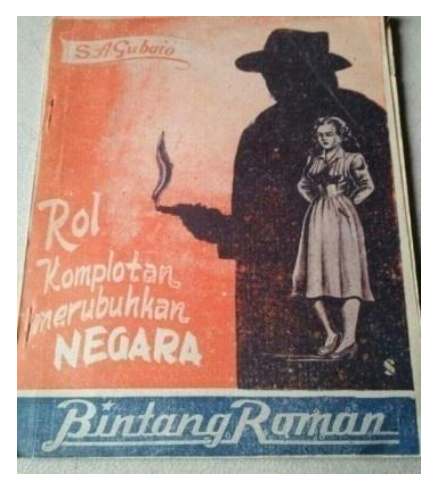

Gambar 7:

Roman Rol Komplotan Merubuhkan Negara (1955) adalah cerita pengintaian berbumbu konflik batin antara cinta dan kewajiban tokohnya sebagai aparat negara. 
Kurang lebih 35 tahun roman Medan telah berkiprah dan memperkaya dunia kesusastraan Indonesia. Para pengarang roman Medan dengan tegas menggambarkan kondisi Kota Medan dengan bahasa yang sederhana dan terus terang. Hal tersebut juga dikarenakan para pengarang tidak mau mengabdikan hidupnya kepada gubernemen Belanda, sehingga mereka lebih memilih untuk menjadi penulis roman Medan dengan segala rintangan yang dihadapinya.

\section{Dampak Penulisan roman Medan}

Penulisan roman Medan memiliki beberapa dampak terhadap kehidupan masyarakat Medan. Diantaranya Pertama, Bidang Politik, kehadiran roman Medan dimanfaatkan oleh penulis untuk menumbuhkan rasa kebangsaan melalui tema-tema pergerakan dalam roman Medan. Roman ini digunakan oleh pengarangnya untuk menyampaikan rasa nasionalisme mereka dan juga menjadi corong suara nasionalisme itu. Penggerak penerbitan di Medan secara tegas dan sadar menyatukan diri dengan kehidupan politik

Kedua, Bidang Pendidikan, roman Medan yang terbit begitu banyak dapat menjadi alternatif bacaan yang memang masih sangat kurang pada masa itu disaat rakyat sudah mulai bisa membaca. Roman menjadi bacaan yang digemari oleh masyarakat dengan bahasanya yang segar dan akrab bagi masyarakat umum, tanpa harus menggunakan bahasa yang metaforik.

Ketiga, Bidang Sosial dan Budaya, kehadiran roman Medan dapat menjadi sumber nilai bagi masyarakat. Dengan adanya cerita yang beraliran realisme maka pola pikir masyarakat akan terbangun. Masyarakat akan lebih mempertimbangkan nilai-nilai yang ada pada karya tersebut karena karya tersebut mengemukakan alasan dan konsekuensi yang kongkrit dalam kehidupan sehari-hari.

\section{PENUTUP}

Beberapa kesimpulan dan saran yang dapat diambil dari penulis berdasarkan hasil penelitian diatas adalah sebagai karya sastra yang sudah dilupakan oleh sebagian orang pada saat ini dan buku-bukunya yang mulai sulit ditemukan, roman Medan tidak hanya menjadi sebuah karya sastra yang sudah hilang oleh zaman. Namun, juga merupakan simbol kejayaan karya sastra Kota Medan yang memiliki nilai sejarah yang tinggi, karena roman Medan telah berkontribusi dalam memperjuangkan kemerdekaan Indonesia. Oleh 
karena itu, harapan penulis agar seluruh masyarakat dan pemerintah Kota Medan, senantiasa menyelamatkan dan melestarikan peninggalan seni-budaya warisan Sumatera Utara ini sebagai salah satu aset bersejarah yang ada di Kota Medan khususnya dalam bidang literasi.

\section{REFERENSI}

Aiyub, dkk. (2000). Sejarah Pertumbuhan Sastra Indonesia di Sumatera Utara. Jakarta: Pusat Pembinaan dan Pengembangan Bahasa.

Amin, M. Yakub. (2015). Historiografi Sejarawan Informal Review Atas Karya Sejarah Joesoef Sou'yb. Medan: Perdana Publishing.

Cakrawala Pendidikan. (Online), No.3, (https://journal.uny.ac.id/index.php/cp/article/d ownload, diakses 26 Agustus 2019).

Kratz, E. Ulrich. (2000). Sumber Terpilih Sejarah Sastra Indonesia Abad XX. Jakarta: Kepustakaan Populer Gramedia (KPG).

Lubis, Koko Hendri. (2018). Roman Medan Sebuah Kota Membangun Harapan. Jakarta: PT Gramedia Pustaka Utama.

Sayekti, Sri. (2011). "Rasa Kebangsaan dalam Roman Medan". Jurnal Pendidikan dan Kebudayaan. (Online), Vol.17, No.6, (http://jurnaldikbud.kemdikbud.go.id/i ndex.php/jpnk/article/view/63/6, diakses 10 Maret 2019).

Sjamsuddin, Helius. (2012). Metodologi Sejarah. Yogyakarta: Ombak.

Sudarmoko. (2009). "Roman Pergaoelan, Penulisan Sejarah, dan Kanonisasi Sastra Indonesia". Jurnal Humaniora. (Online), Vol.21, No.1, (https://www.academia.e du/1862962/Roman_Pergaoelan_Penulisan_Sejarah_dan_Kanonisasi_Sastra_Ind onesia, diakses 26 Agustus 2019).

Sulasman, H. (2014). Metodologi Penelitian Sejarah: Teori, Metode, dan Contoh Aplikasi. Bandung: Pustaka Setia.

Umry, Shafwan Hadi. (2016). Gelombang Sastra Kajian Konstektual. Medan: CV. Partama Mitra Sari

Zaidan, Abdul Rozak dkk. (2005). Revolusi, Nasionalisme, dan Banjir Roman. Jakarta: Pusat Bahasa Departemen Pendidikan Nasional. 